University of Nebraska - Lincoln

DigitalCommons@University of Nebraska - Lincoln

Agronomy \& Horticulture - Faculty Publications

Agronomy and Horticulture Department

2017

\title{
Can Cover Crop Use Allow Increased Levels of Corn Residue Removal for Biofuel in Irrigated and Rainfed Systems?
}

\author{
S. J. Ruis \\ University of Nebraska-Lincoln, sruis2@unl.edu \\ Humberto Blanco-Canqui \\ University of Nebraska-Lincoln, hblanco2@unl.edu \\ Paul J. Jasa \\ University of Nebraska-Lincoln, pjasa1@unl.edu \\ R. B. Ferguson \\ University of Nebraska-Lincoln, rferguson1@unl.edu \\ G. Slater \\ University of Nebraska-Lincoln, gslater1@unl.edu
}

Follow this and additional works at: https://digitalcommons.unl.edu/agronomyfacpub

Part of the Agricultural Science Commons, Agriculture Commons, Agronomy and Crop Sciences Commons, Botany Commons, Horticulture Commons, Other Plant Sciences Commons, and the Plant Biology Commons

Ruis, S. J.; Blanco-Canqui, Humberto; Jasa, Paul J.; Ferguson, R. B.; and Slater, G., "Can Cover Crop Use Allow Increased Levels of Corn Residue Removal for Biofuel in Irrigated and Rainfed Systems?" (2017). Agronomy \& Horticulture -- Faculty Publications. 1052.

https://digitalcommons.unl.edu/agronomyfacpub/1052

This Article is brought to you for free and open access by the Agronomy and Horticulture Department at DigitalCommons@University of Nebraska - Lincoln. It has been accepted for inclusion in Agronomy \& Horticulture -Faculty Publications by an authorized administrator of DigitalCommons@University of Nebraska - Lincoln. 


\title{
Can Cover Crop Use Allow Increased Levels of Corn Residue Removal for Biofuel in Irrigated and Rainfed Systems?
}

\author{
S. J. Ruis, ${ }_{1}^{1}$ H. Blanco-Canqui, ${ }^{1}$ P. J. Jasa, ${ }^{2}$ R. B. Ferguson, ${ }^{1}$ \\ and G. Slater ${ }^{3}$ \\ 1 Department of Agronomy and Horticulture, University of Nebraska-Lincoln, \\ Lincoln, NE 68583, USA \\ 2 Department of Biological Systems Engineering, University of Nebraska-Lincoln, \\ Lincoln, NE 68583, USA \\ 3 South Central Agricultural Laboratory, University of Nebraska-Lincoln, Clay \\ Center, NE 68933, USA \\ Corresponding author — S. J. Ruis, sruis2@unl.edu
}

\begin{abstract}
Corn (Zea mays L.) residue removal at high rates can result in negative impacts to soil ecosystem services. The use of cover crops could be a potential strategy to ameliorate any adverse effects of residue removal while allowing greater removal levels. Hence, the objective of this study was to determine changes in water erosion potential, soil organic $\mathrm{C}$ (SOC) and total $\mathrm{N}$ concentration, and crop yields under early- and lateterminated cover crop (CC) combined with five levels of corn residue removal after 3 years on rainfed and irrigated no-till continuous corn in Nebraska. Treatments were no CC, early- and late-terminated winter rye (Secale cereale L.) CC, and 0, 25, 50, 75, and 100\% corn residue removal rates. Complete residue removal reduced mean weight diameter (MWD) of water-stable aggregates ( $5 \mathrm{~cm}$ depth) by $29 \%$ compared to no removal at the rainfed site only, suggesting increased water erosion risk at rainfed sites. Late-terminated CC significantly increased MWD of water-stable aggregates by 27 to $37 \%$ at both sites compared to no CC, but earlyterminated CC had no effect. The increased MWD with late-terminated CC suggests that $C C$ when terminated late can offset residue removal-induced risks of water erosion. Residue removal and CC did not affect SOC and total soil $\mathrm{N}$ concentration. Particulate organic matter increased with lateterminated CC at the irrigated site compared to no CC. Complete residue removal increased irrigated grain yield by $9 \%$ in 1 year relative to no
\end{abstract}


removal. Late-terminated CC had no effect on corn yield except in 1 year when yield was $8 \%$ lower relative to no CC due to low precipitation at corn establishment. Overall, late-terminated CC ameliorates residue removalinduced increases in water erosion potential and could allow greater levels of removal without reducing corn yields in most years, in the short term, under the conditions of this study.

Keywords: Cover crop, Residue removal, Corn yield, Aggregate stability, Soil organic C, Mean weight diameter, Winter rye, Early termination, Late termination

\section{Introduction}

Corn residue is currently the main targeted cellulosic feedstock for biofuel production because it is readily available in large quantities [16, 21, 42]. Perennial warm-season grasses are under consideration [34,38], but large field-scale production of such feedstock sources is still limited. For example, perennial grass biomass yields in marginal lands are more variable ( 1 to $14 \mathrm{Mg} \mathrm{ha}^{-1}$ ) [9] than corn residue yield (5 to $12 \mathrm{Mg} \mathrm{ha}^{-1}$ ) [19, 40]. Furthermore, some studies suggest that corn residue removal at $50 \%$ could result in more ethanol production potential than switchgrass biomass per unit of area [20].

The concern, however, is that excessive removal of crop residues for biofuel production could increase risks of soil erosion and adversely affect soil properties, nutrient cycling, and long-term soil productivity [22, 42, 43]. As rates of residue removal increase, the adverse effects of residue removal on soil properties and subsequent soil ecosystem services could also increase $[3,6,19,31]$. Residue removal can increase soil erosion [10, $11,19,20]$, reduce soil organic $C$ (SOC) pools [20, 21, 36, 42], long-term soil productivity [5, 19, 20,37,42], and other soil services [42]. According to Wilhelm et al. [43], about $5.25 \mathrm{Mg} \mathrm{ha}^{-1}$ of corn residues are required to maintain SOC under no-tillage or conservation tillage with continuous corn in Midwestern soils including loam, silt loam, and silty clay loam, while residue cover of at least $55 \%$ is required to prevent water and wind erosion in continuous no-till corn in loamy and silty clay loam soils $[10,11]$.

Previous studies suggest that only 30 or $50 \%$ of corn residues can be sustainably removed for biofuel $[5,16,42,43]$. A recent study concluded that only $1.6 \mathrm{Mg} \mathrm{ha}^{-1}$ of residue (28 million Mg across the Corn Belt) could be sustainably harvested for biofuel production [37]. These removal rates are unlikely to meet the large amount of feedstock required for biofuel production. Approximately 46 million ha at $6 \mathrm{Mg} \mathrm{ha}^{-1}$ of residue harvest are needed to meet the goals set by the US Energy Independence Security Act [21].

Improved management practices are therefore needed to allow greater amounts of corn residue removal. One such management practice can be the use of cover crop (CC) following residue removal. Pratt et al. [27] suggested that addition of CC to current corn production systems could allow for $1.8 \mathrm{Mg} \mathrm{ha}^{-1}$ more residue removal for biofuel production than 
fields without CC while maintaining or improving soil services. Cover crop biomass production may range from 0.5 to $6.9 \mathrm{Mg} \mathrm{ha}^{-1}$ [15]. This level of CC biomass production could ameliorate residue removal effects on soil properties because it can provide additional aboveground and belowground biomass input. In other words, the additional biomass input from CC can supplant the soil benefits lost with residue removal. This strategy could be feasible because it does not require a major change in current cropping systems. From the financial standpoint of the farmer, use of CC following residue removal could improve farm profit through improvement in soil ecosystem services [26]. Furthermore, it could contribute to the sustainable diversification of traditional cropping systems. However, information from field studies comparing effects of corn residue removal at different rates with and without CC on ecosystem services such as water erosion potential, soil fertility, soil organic $C$, and crop yields is limited $[1,7,35,41]$.

Corn is grown in both rainfed and irrigated lands worldwide. The level of corn residue removal for biofuel and the potential of CC to mitigate removal effects could vary with irrigation management. For example, residue removal from rainfed fields may have larger negative impacts on soils and crop yields compared with irrigated soils under the same level of residue removal due to lower residue production in rainfed systems; however, this has not been well documented. Most residue removal studies are from rainfed corn production systems [1, 26, 35, 41] and not from irrigated systems [19]. Residue production may be higher in irrigated corn than in rainfed corn. Thus, information regarding residue removal effects on soil properties is also needed in irrigated systems.

Early-terminated CC may not be as effective as late-terminated CC at offsetting negative effects of residue removal due to low biomass production. However, it is important to consider that late-terminated CC could also reduce subsequent crop yields in water-limited regions [24, 25, 30]. Further, much of the work with CC is confined to rainfed locations [ 1 , 7, 14, 16]. Thus, experimental data from irrigated locations are limited although CC is not commonly irrigated $[23,24,30]$. Currently, there are no studies on how CC termination date combined with different rates of corn residue removal for biofuel affect soil and corn yields in both irrigated and rainfed regions. Our study is designed to address this knowledge gap. The objective of this study was to determine changes in soil properties and corn yield under early- and late-terminated CC combined with five different levels of corn residue removal on a rainfed and an irrigated notill continuous corn system in Nebraska after 3 years of management.

\section{Materials and Methods}

Description of Study Sites and Experimental Treatments Two sites were used: (1) the University of Nebraska-Lincoln (UNL) Rogers Memorial Farm (RMF) near Lincoln, NE (40.846 $\mathrm{N}$ lat; $96.472^{\circ} \mathrm{W}$ long; $380 \mathrm{~m}$ asl), and (2) UNL South Central Agricultural Laboratory (SCAL) near Clay Center, NE 
( $40.582^{\circ} \mathrm{N}$ lat; $98.144^{\circ} \mathrm{W}$ long; $552 \mathrm{~m}$ asl). The soil at RMF was an Aksarben silty clay loam (fine, smectitic, mesic Typic Argiudolls) with about $3 \%$ slope, while the soil at SCAL was a Hastings silt loam (fine, smectitic, mesic Udic Argiustoll) with $<1 \%$ slope. Both sites were under no-till continuous corn management. The site at RMF was planted to white corn while the site at SCAL was planted to yellow corn. The site at RMF was rainfed while the site at SCAL was sprinkler irrigated. For discussion purposes, site identification will be rainfed for RMF and irrigated for SCAL. The rainfed site was under no-till for 20 years prior to establishing the experiment, while the irrigated site was under ridge till. The 30 -year mean annual temperature was $10{ }^{\circ} \mathrm{C}$ for the rainfed site and $13{ }^{\circ} \mathrm{C}$ for the irrigated site (Table 1). Mean annual precipitation across the study years was $860 \mathrm{~mm}$ at the rainfed site and $655 \mathrm{~mm}$ at the irrigated site, while the 30-year mean annual precipitation was $818 \mathrm{~mm}$ at the rainfed site and $688 \mathrm{~mm}$ at the irrigated site (Table 1). Initial SOC concentrations across treatment plots were $23.6 \mathrm{~g} \mathrm{~kg}^{-1}$ for the rainfed site and $22.0 \mathrm{~g} \mathrm{~kg}^{-1}$ for the irrigated site.

We conducted a 3-year study on a winter rye CC following corn residue removal beginning fall of 2013. The experimental design is a factorial with treatments arranged in a randomized complete block design. The treatments were five residue removal rates $(0,25,50,75$, and $100 \%)$ and three winter rye CC treatments (no CC, early and late termination) with four replications for a total of 60 plots per site $(5$ removal rates $\times 3 \mathrm{CC}$ treatments $\times 4$ replications $=60$ experimental units). The plot size was 10 $\mathrm{m}$ by $10 \mathrm{~m}$ at the rainfed site and $10 \mathrm{~m}$ by $7.5 \mathrm{~m}$ at the irrigated site. Each plot had 12 corn rows.

Table 2 shows the main field operations performed at each site. Planting of corn occurred at 80,000 plants ha ${ }^{-1}$ in late April each year at the rainfed site and at 84,016 plants ha ${ }^{-1}$ in early May at the irrigated site. Application of residue removal treatments to each plot occurred in fall in mid- to late October each year. Application of the residue removal treatments is described later. Drilling of CC occurred in fall after corn harvest. Cereal rye CC was planted at rates of $67 \mathrm{~kg} \mathrm{ha}^{-1}$ at the rainfed site and 56 to $112 \mathrm{~kg}$ $\mathrm{ha}^{-1}$ at the irrigated site in late October to early November. The earlyterminated CC treatment was chemically terminated in mid-April about 2 to 3 weeks before planting corn, while the late-terminated CC treatment occurred within a few days before or after planting corn in mid-May (Table 2). Application of residue removal treatments, planting of $C C$, and termination of $C C$ varied annually depending on weather conditions. Cover crop seeding rate increased at the irrigated site in the last 2 years (2015 and 2016) of the experiment to achieve a better stand in the fall due to late corn harvest. Cover crops were not irrigated.

\section{Soil Collection and Analysis}

To evaluate changes in soil properties under the different rates of residue removal with and without $\mathrm{CC}$, we measured wet aggregate stability and concentrations of particulate organic matter (POM), SOC, and total soil $\mathrm{N}$ after 3 years of management. These properties were selected because they 
can be more responsive to management changes than other properties in the short term $[4,11]$. Soil was sampled in May 2016 at both sites after corn planting. Six soil samples of $3.1 \mathrm{~cm}$ diameter were collected from the shoulder of corn rows within each plot using a hand probe, separated into 0 - to $5-\mathrm{cm}$ and 5 - to $10-\mathrm{cm}$ depths, and composited by depth. Because changes in soil properties are often confined to near-surface layers in the short term, samples were not collected from deeper depths. The composite samples were gently crushed to pass an 8-mm sieve and airdried in a forced air oven at $65^{\circ} \mathrm{C}$ for 3 days.

To assess changes in water erosion potential, we determined wet aggregate stability using the wet-sieving method [18]. The air-dried soil samples were sieved to collect $4.75-$ to $8-\mathrm{mm}$ aggregates. About $50 \mathrm{~g}$ of the aggregates were placed on nested sieves with openings of $4.75,2.00$, $1.00,0.50$, and $0.25 \mathrm{~mm}$ and re-wetted through capillary action for $10 \mathrm{~min}$. Nested sieves were then mechanically sieved in water for 30 oscillations $\mathrm{min}^{-1}$ for $10 \mathrm{~min}$. Aggregates on each sieve were washed into beakers and oven dried at $105^{\circ} \mathrm{C}$ for $48 \mathrm{~h}$ to obtain mass of the aggregate fraction and then we computed mean weight diameter (MWD) of aggregates [17]. To characterize soil porosity, which can affect runoff or water erosion, bulk density was determined by the core method. Soil cores were collected using a hand probe for the 0 - to 5 - and 5 - to $10-\mathrm{cm}$ depths. Soil porosity was computed using bulk density data assuming particle density equal to $2.65 \mathrm{~g} \mathrm{~cm}^{-3}$ [4].

To assess changes in the labile fraction of soil organic matter, we determined POM concentration on a 30-g air-dried sample, dispersed with $5 \mathrm{~g} \mathrm{~L}^{-1}$ sodium hexametaphosphate for $24 \mathrm{~h}$ on a reciprocal shaker. Dispersed soil was passed through a $0.53-\mu \mathrm{m}$ sieve and rinsed until clear. Particulate organic matter was rinsed into aluminum tins and dried at 60 ${ }^{\circ} \mathrm{C}$ to constant weight. Mass of POM $(>0.53 \mu \mathrm{m})$ was recorded. Samples were heated to $450{ }^{\circ} \mathrm{C}$ in a muffle furnace for $4 \mathrm{~h}$ and weighed. The concentration (mg POM kg${ }^{-1}$ soil) of POM was then calculated [12].

To evaluate losses or gains in soil $C$ and fertility, we determined concentrations of SOC and total $\mathrm{N}$ using the dry combustion method [23]. A portion of the air-dried soil samples was ground to pass a $2 \mathrm{~mm}$ sieve, and about $10 \mathrm{~g}$ were ground to flour-like consistency with mortar and pestle. Samples were placed in scintillation vials with steel rods and ground on a roller mill for $24 \mathrm{~h}$ before analysis on a Flash $2000 \mathrm{C}$ and $\mathrm{N}$ analyzer (CE Elantech, Lakewood, NJ).

\section{Agronomic Parameters}

Corn plant height was measured in 2016 on 10 plants in mid- May and at tasseling in July. The height was measured from the soil surface to the extended top leaf on the same plants from two central rows. To explain any possible differences in plant height among treatments, we monitored changes in soil temperature and moisture for CC treatments under 0, 50, and $100 \%$ removal levels in 2016 at the time of plant height measurement. Soil temperature was measured using digital thermometers at $5-\mathrm{cm}$ depth, 
while soil moisture was measured at $12-\mathrm{cm}$ depth with a time domain reflectometry probe (Spectrum Technologies, Inc., Aurora, IL).

Cover crop biomass was harvested in early April for early-terminated CC and late April or early May for late-terminated CC. Biomass was clipped at soil level from two $0.25-\mathrm{m}^{2}$ quadrats from each plot, air-dried at $65^{\circ} \mathrm{C}$ for 2 days, and weighed. Cover crop biomass yield was then scaled up to a $\mathrm{Mg}$ ha $^{-1}$ basis and assumed to have $0 \%$ moisture content at weighing. Corn grain and stalks were harvested from the center two rows of each plot for a length of $2 \mathrm{~m}$ to determine grain and residue yield. Corn ears were removed from the stalk without removing husks, and stalks were cut at soil level. Corn ears and stalks were weighed in the field. Three ears and three stalks were randomly selected from the harvested ears and stalks for air drying at $65^{\circ} \mathrm{C}$ for $48 \mathrm{~h}$ before weighing. Grain was removed from the ears using a hand sheller. Both cobs and grain were dried for $24 \mathrm{~h}$ at $65{ }^{\circ} \mathrm{C}$ before weighing each component and calculating yield assuming $15.5 \%$ moisture content [5]. The field masses of stalks (residue) and corn ears were then corrected for moisture content and scaled up to $\mathrm{Mg} \mathrm{ha}^{-1}$ using the area harvested to obtain the subsample.

To apply residue removal treatments, corn stalks were shredded at 10$\mathrm{cm}$ height and residue was manually removed. To achieve the $25,50,75$, and $100 \%$ removal rates, residue was removed from select rows and remaining residue redistributed. For example, to achieve $50 \%$ residue removal, we removed residue from six of the 12 rows and the remaining residue in the plot was redistributed among all 12 rows.

\section{Statistical Analysis}

Data were analyzed by site (rainfed and irrigated) to assess statistical differences among CC termination date and residue removal treatments using PROC MIXED in SAS software for a randomized complete block design [29]. The PROC MIXED in SAS was used to analyze data on wet aggregate stability (MWD), SOC, total soil N, particulate organic matter, CC biomass, corn growth, corn yield, stover yield, soil temperature, and soil moisture. Prior to analysis of treatment effects, normal distribution of data was studied using the Shapiro-Wilk test in PROC UNIVARIATE in SAS software by site and across all treatments. Data were normally distributed and no transformation was performed. Fixed factors were CC and corn residue removal rate, while the random factor was replication. Data were analyzed by year for CC biomass, corn yield, and stover yield. Data for MWD and particulate organic matter were analyzed by soil depth. Data for corn growth, soil temperature, and soil moisture were analyzed by date. Separation of treatment means was conducted through least significant differences at the 0.05 probability level, unless otherwise stated. 


\section{Results}

\section{Water Erosion Potential}

Residue removal affected mean weight diameter of water-stable aggregates at the rainfed site $(p=0.09)$ and at the irrigated site $(p=0.09)$. Cover crop termination date affected mean weight diameter at both sites ( $p=0.0097$ for rainfed and $p=0.0005$ for irrigated). The interaction of residue removal $\times$ CC termination date was not significant ( $p=0.54$ for rainfed and $p=0.14$ for irrigated). Residue removal and CC termination date affected mean weight diameter only in the 0 - to 5 - $\mathrm{cm}$ depth (Figs. $1 \mathrm{a}$, $\mathrm{b}$ and $2 \mathrm{a}, \mathrm{b}$ ) and not in the $5-$ to $10-\mathrm{cm}$ depth (data not shown). At the rainfed site, residue removal effects on mean weight diameter were significant only between 100 and $\leq 50 \%$ removal rates. Complete removal reduced mean weight diameter $(1.19 \pm 0.39 \mathrm{~mm})$ by up to $31 \%$ compared to $\leq 50 \%$ removal rates $(1.56 \pm 0.42 \mathrm{~mm}$ ) (Fig. 1a). Late-terminated CC treatment increased mean weight diameter $(1.70 \pm 0.31 \mathrm{~mm})$ by $27 \%$ relative to control $(1.34 \pm 0.52 \mathrm{~mm})$ (Fig. $1 \mathrm{~b})$. At the irrigated site, residue removal at rates above $50 \%$ tended to reduce mean weight diameter but statistically, mean weight diameter was variable across residue removal rates (Fig. 2a). At this site, late-terminated CC increased mean weight diameter $(1.21 \pm 0.34 \mathrm{~mm})$ by $37 \%$ compared to no CC $(0.88 \pm 0.25 \mathrm{~mm})$ (Fig. 2b). Early-terminated CC had no effect on wet aggregate stability at any either site. Changes in soil porosity influence water erosion. However, in this study, treatments did not affect soil porosity. Mean porosity across treatments was $0.53 \mathrm{~cm} \mathrm{~cm}^{-3}$ at the rainfed site and $0.52 \mathrm{~cm} \mathrm{~cm}^{-3}$ at the irrigated site.

\section{Soil Organic Carbon, Total Nitrogen, and Particulate Organic Matter}

Residue removal and CC termination date did not affect SOC and total $\mathrm{N}$ concentrations at either site (Table 3). Although not significant, mean SOC concentration tended to decrease with residue removal at the rainfed site but not at the irrigated site (Table 3). Cover crops tended to increase SOC concentration at both sites (Table 3). Residue removal did not affect POM concentration at either site; however, CC termination date affected POM concentration in the $0-$ to $5-\mathrm{cm}$ depth at the irrigated site. Particulate organic matter was $13.5 \%\left(2 \mathrm{mg} \mathrm{g}^{-1}\right)$ greater with late-terminated than early-terminated CC and control at the irrigated site. Residue removal and CC termination date had no effect on POM concentration at the 5- to 10$\mathrm{cm}$ depth (data not shown).

\section{Cover Crop Biomass Yield}

At the rainfed site, residue removal affected late-terminated CC biomass yield in the second (2015) and third year (2016) of the study. At the irrigated site, residue removal affected CC biomass yield only in the first year. Cover crop termination date (Table 2), as expected, affected CC 
biomass yield at both sites in all years (Table 4). There was an interaction of residue removal $\times C C$ at the irrigated site in the first year and at the rainfed site in the second year. At the rainfed site, complete residue removal increased CC biomass yield by $83 \%$ in the second year compared with the rest of the removal rates. At the same site, in the third year, complete residue removal increased CC biomass yield by $63 \%$ but only when compared with no removal. At the same site, late-terminated CC increased CC biomass yield by 11 times $\left(0.03\right.$ vs. $\left.0.32 \mathrm{Mg} \mathrm{ha}^{-1}\right)$ in the first year, by 1.88 times ( 0.80 vs. $\left.1.50 \mathrm{Mg} \mathrm{ha}^{-1}\right)$ in the second year, and by 2 times (1.41 vs. $3.00 \mathrm{Mg} \mathrm{ha}^{-1}$ ) in the third year compared to earlyterminated CC. At the irrigated site, under early-terminated CC, complete residue removal increased CC biomass yield by $63 \%$ in the first year compared with no removal. At the same site, late-terminated CC increased CC biomass yield by 16 times ( 0.15 vs. $\left.2.44 \mathrm{Mg} \mathrm{ha}^{-1}\right)$ in the first year, by 11 times ( 0.19 vs. $\left.2.03 \mathrm{Mg} \mathrm{ha}^{-1}\right)$ in the second year, and by 9 times ( $0.45 \mathrm{vs.}$ $\left.4.12 \mathrm{Mg} \mathrm{ha}^{-1}\right)$ in the third year compared with early-terminated CC.

\section{Corn Growth and Yield}

Residue removal affected corn height at both sites but CC had no effect. At the rainfed site, early in the growing season, corn under $0 \%$ removal was shorter $(19.9 \mathrm{~cm})$ than under $50 \%(21.7 \mathrm{~cm})$ or $100 \%(25.2 \mathrm{~cm})$ removal treatments. However, at tasseling, corn height did not differ among the residue removal treatments. At the irrigated site, early in the growing season, corn was taller $(25.2 \mathrm{~cm})$ in $100 \%$ than in $0 \%(19.9 \mathrm{~cm})$ and $50 \%$ $(21.7 \mathrm{~cm})$ residue removal treatments. At tasseling, corn was similar in height across all treatments.

Residue removal had a significant effect on corn grain yield only at the irrigated site in the second year. Residue removal at 25,75 , and $100 \%$ increased grain yield by $11 \%$ compared to no removal (Table 5). Cover crop affected grain yield at both sites in the second year. Late-terminated CC reduced grain yield by $8 \%$ compared to no CC treatment. Across years, residue removal and CC termination date did not affect corn yield (Table 5). Residue removal and CC termination date had no effect on residue yield in any year or site. At the rainfed site, mean residue yield was $9.05 \mathrm{Mg} \mathrm{ha}^{-1}$ in $2014,9.50 \mathrm{Mg} \mathrm{ha}^{-1}$ in 2015 , and $11.0 \mathrm{Mg} \mathrm{ha}^{-1}$ in 2016 . At the irrigated site, mean residue yield was $10.23 \mathrm{Mg} \mathrm{ha}^{-1}$ in $2014,9.03 \mathrm{Mg} \mathrm{ha}^{-1}$ in 2015, and $11.30 \mathrm{Mg} \mathrm{ha}^{-1}$ in 2016 .

\section{Soil Temperature and Soil Water Content}

Residue removal affected soil temperature for the measurement depth (5 $\mathrm{cm})$ at both sites in May. Residue removal at $100 \%$ increased soil temperature by 1 to $3{ }^{\circ} \mathrm{C}$ at the rainfed site and by up to $5{ }^{\circ} \mathrm{C}$ at the irrigated site relative to the control in May. Residue removal and CC termination date did not affect soil water content at the rainfed site, but it affected soil water content in July at the irrigated site. At this site, complete 
residue removal reduced soil water content by $37 \%$ compared to the control in July.

\section{Discussion}

\section{Water Erosion Potential}

The results from this study showing a decrease in the size of water-stable aggregates with complete residue removal at the rainfed site and general decrease in size of water-stable aggregates at the irrigated site after 3 years suggest that excessive residue removal could increase water erosion potential (Figs. 1 and 2). Wet aggregate stability is a sensitive indicator of water erosion potential [2]. The reduction in soil aggregate stability at the rainfed site could be associated with the decrease in SOC concentration at this site (Table 3). The increased water erosion potential with complete residue removal at the rainfed site is similar to that reported in Kansas [19] and South Dakota [41].

The lack of strong differences in wet aggregate stability at the irrigated site in the short term suggests that irrigated soils could be more resilient to residue removal and could probably sustain greater amounts of removal without reducing soil structural quality and increasing water erosion risks. Similar to this study, a study in Kansas found no effects of residue removal on aggregate stability in two irrigated sites [19]. Collectively, our study and previous studies $[19,41]$ suggest that the level of residue removal from rainfed systems should be lower than from irrigated sites.

The increase in wet aggregate stability with late-terminated CC and lack of change in wet aggregate stability between early-terminated CC and no CC at both sites strongly suggest that late-terminated CC can improve soil structural quality and reduce water erosion potential regardless of irrigation regime. The increased wet aggregate stability under lateterminated CC relative to early-terminated CC can be due to the greater biomass production under late-terminated CC (Table 4). The study results appear to suggest that there may be a minimum CC biomass yield needed to improve soil structure. Cover crop biomass yield across the 3 years was $0.51 \mathrm{Mg} \mathrm{ha}^{-1}$ under early CC termination and $1.61 \mathrm{Mg} \mathrm{ha}^{-1}$ under late CC termination. This suggests that CC biomass yield above $1 \mathrm{Mg} \mathrm{ha}^{-1}$ could increase soil aggregate stability and offset the effects of crop residue removal. Minimum CC biomass amount required to improve MWD may vary depending on site characteristics such as irrigation and soil texture. For example, our results appear to suggest that lower CC biomass yield is required to increase MWD in rainfed sites $\left(2.25 \mathrm{Mg} \mathrm{ha}^{-1}\right.$ averaged across 2015 and 2016), while more CC biomass yield could be needed in irrigated sites (>3.30 Mg ha ${ }^{-1}$ averaged across 2015 and 2016). Further studies evaluating threshold levels of CC biomass production needed to improve soil properties are warranted.

The results of increased soil structural quality (MWD) with lateterminated CC indicate that this CC management strategy could allow for 
greater levels of corn residue removal compared to no or early-terminated CC in both rainfed and irrigated systems. However, terminating CC early, 1 to 3 weeks before main corn crop planting, appears to have no effect on offsetting the corn residue removal effects on water erosion potential (Fig. 1b). Previous studies on early-terminated CC following residue removal have found mixed results with regard to soil aggregate stability. On a rainfed site in eastern South Dakota, CC did not affect wet aggregate stability after residue removal for 4 and 6 years $[35,41]$, but on an irrigated site in south central Nebraska, CC increase wet aggregate stability and ameliorate the residue removal effects [7]. The increased aggregate stability under the late-terminated CC at the rainfed site cannot be compared with other studies as data are not available. Overall, results suggest that, in rainfed and irrigated sites, late-terminated CC offer promise to ameliorate residue removal effects on wet aggregate stability, potentially allowing increased levels of residue removal.

The smaller MWD of soil aggregates at the irrigated than at the rainfed site (Fig. 2) was likely due to the following factors. First, soil textural class was silt loam at the irrigated site and silty clay loam at the rainfed site. The greater clay content in the rainfed site likely allowed for greater aggregate stability [32]. Second, the irrigated site was previously under ridge till and disked before establishment of the experiment, whereas the rainfed site was under no-till for 20 years prior to experiment initiation. Thus, tillage operations at the irrigated site probably disrupted soil aggregates, leading to lower aggregate size [33].

\section{Soil Organic Carbon}

Residue removal even at high rates (100\%) appears not to reduce SOC concentration in rainfed and irrigated soils after 3 years. We expected that near-surface $(5 \mathrm{~cm}) \mathrm{SOC}$ concentration would have decreased rapidly with high ( $>50 \%$ ) rates of residue removal as microbes would use older SOC as a substrate for energy due to the lack of fresh aboveground residue input [35]. Root-derived SOC possibly offset any decrease in SOC due to aboveground residue removal. Previous work indicates that only about $40 \%$ of the aboveground residues left on a field can be incorporated into SOC [32]. Most contributions to SOC originate from roots [42]. Despite much of the root contribution to SOC, estimates show that excessive residue removal can consistently reduce SOC storage in corn production systems [21], but our experimental data after 3 years of residue management do not support such estimates. The trend for decreased SOC concentration with residue removal (Table 3 ) and the trend for increased SOC concentration with CC (Table 3) suggest that CC could partly offset residue removal effects on $\mathrm{SOC}$, but long-term monitoring of $\mathrm{SOC}$ in these ongoing experiments is required for definitive conclusions. Results from this study are similar to previous field studies, which showed trends for increased SOC in both rainfed and irrigated sites [7, 35, 41].

Results showed that SOC concentration was unaffected by residue removal, including 100\% removal of corn residues after 3 years, which 
suggests that, in the short term, even high rates of residue removal do not reduce SOC concentrations. Long-term monitoring is needed to determine the length of time at which complete removal could reduce SOC concentration in these and similar soils. The soil organic matter concentration was $4.8 \%\left(48 \mathrm{~g} \mathrm{~kg}^{-1}\right)$ at the rainfed site with $<3 \%$ slope and $4.3 \%\left(43 \mathrm{~g} \mathrm{~kg}^{-1}\right)$ at the irrigated site with $<1 \%$ slope. These levels of soil organic matter are higher than those in marginally productive or degraded croplands. Some studies have suggested that at least $5.25 \mathrm{Mg} \mathrm{ha}^{-1}$ of residues per year is needed to maintain SOC levels [42]. This study suggests that, in the short term, even complete removal of aboveground residues may not reduce SOC levels. As discussed earlier, root-derived SOC can be a major factor that offsets the aboveground residue removal effects. However, we hypothesize that continued residue removal at high rates could reduce SOC levels.

Since POM is a precursor to SOC, it could respond to residue management changes sooner. We expected that residue removal, especially at high rates, could reduce POM concentration because microbes continually use this as a substrate, but in our study, we observed no changes in POM concentration except with late-terminated CC at the irrigated site. The increase in POM concentration with late-terminated CC at the irrigated site could be attributed to the greater biomass yield in the irrigated than in the rainfed site. A higher seeding rate was used in the irrigated site in the third year (Table 2). The increase in POM concentration with late-terminated and not early-terminated CC at the irrigated site is probably due to the lower biomass yield under early termination. A few studies showed mixed effects of CC on POM $[7,26]$.

\section{Cover Crop Biomass Yield}

The greater CC biomass yield with late-terminated than with earlyterminated CC was due to longer growing time. In 2015 and 2016, warmer than average temperatures in November and March probably allowed for longer CC growing season, but limited precipitation November 2014 and March 2015 likely minimized the differences in biomass yield between early and late-terminated CC in 2015 (Tables 1 and 4). By contrast, the wetter and warmer weather in March 2016 likely contributed to the greater CC biomass yield in 2016 compared with the previous years (Table 4). Previous studies on CC termination also showed that late-terminated CC can yield more biomass compared to early-terminated CC $[13,15,28]$.

The range in CC biomass yield in this study was similar to that reported by a modeling study on rainfed soils [15]. The magnitude of biomass yield difference between early- and late-terminated was greater in this field study than the modeled results [15]. This could be due to the difference in termination times between early and late CC, which were 1 to 3 weeks in this study and 1 week in the modeling study. Late-terminated CC biomass yield was greater at the irrigated site than at the rainfed site most likely due to the greater seeding rate and later termination date at the irrigated site. 
Currently, there are no studies that have evaluated the interactive effect of different rates of residue removal on CC biomass yield; however, the increase in CC biomass yield with residue removal under late-terminated CC, in some years, was possibly due to better CC seed-soil contact and emergence of $C C$ in residue removal plots. The greater $C C$ biomass yield with residue removal under late-terminated $C C$ relative to no removal suggests that late-terminated CC could provide significant surface cover and potentially supplant the corn residue benefits. The CC appears to perform better when corn residues are removed than with no removal, indicating that late-terminated CC benefits can be larger or more essential when residues are removed.

\section{Corn Yield}

The increase in corn yield in 1 year at the irrigated site and no changes in corn yield at the rainfed site indicate that residue removal effects on corn yield can be site- or year-specific. No effect of residue removal on corn yield at the rainfed site was likely due to adequate moisture during critical times of corn development (Tables 1 and 5). The higher than average rainfall in 2015 combined with generally warmer temperatures likely provided optimum conditions for corn growth, which resulted in higher yields than in other years. Results from the rainfed site are similar to those reported in Kansas, where residue removal increased corn yield in some years compared to no residue removal [19]. Results, however, differ from a study in Ohio where residue removal reduced corn yield in some years [5]. Similar studies have also shown that increasing rates of corn residue removal may or may not affect corn yield in rainfed locations [42, 43]. The site specificity of residue removal effects on corn yield could mean different levels of residue removal for each site.

The increase in crop yield with $\geq 25 \%$ residue removal at the irrigated site in one of the 3 years suggests that in years with adequate moisture during the growing season (Table 1), residue removal may increase yield in irrigated sites. Other field studies from irrigated sites also showed that residue removal can increase yield in some years [17, 19]. A study across three irrigated fields in eastern Nebraska found that residue removal at rates above $75 \%$ from no-till continuous corn increased yield compared to no residue removal [42]. Our results and those of others suggest that residue removal could generally be beneficial to corn yield in irrigated sites. A modeling study, however, suggested that corn yield may decrease in irrigated sites with residue removal potentially due to lower soil water content from increased evaporation, which may then prompt use of additional irrigation and diminish finite groundwater resources [32].

The 3-year study results showed that early-terminated CC compared to no CC did not affect corn yield in any year. Late-terminated CC reduced corn yield in 1 year, 2015, which was likely due to low rainfall during the early growth stages of the corn. In 2015, rainfall at the time of planting through 3 weeks after planting was about $2.5 \mathrm{~cm}^{\text {week }}{ }^{-1}$; however, the last part of May and early June had low rainfall $<1 \mathrm{~cm}^{\text {week }}{ }^{-1}$ when the young 
corn plants were actively growing. The decrease in corn yield in one out of 3 years could be due to water use by the $\mathrm{CC}$ and reduced soil temperature under CC residues. Measured soil water content at the time of corn planting in 2015 at the rainfed site showed that late-terminated CC under the $100 \%$ residue removal reduced volumetric water content by $37 \%$. A $10-$ year study on an irrigated site near our experimental site showed earlyterminated rye CC reduced silage yield in 4 of 10 years compared to no CC, potentially due to soil water use by the CC [13]. The loss of silage yield with CC use was particularly evident in drought years, and averaged across years, use of rye CC reduced silage yield [14]. Studies using CC showed that water use by the CC may impact yield in some years [8,39].

Late-terminated CC may only have negative effects on grain yield in years with rainfall below average during corn establishment (Table 1). In some cases, the small reduction in corn yield may be irrelevant due to overall greater yields, as observed in this study (Table 5). There are few studies comparing early- and late-terminated CC effects on corn yield. Further, no study has evaluated residue removal and CC termination date interactions. One site in Maryland with late-terminated CC showed increased grain yield [13]. A study assessing a single termination date in Pennsylvania found that the use of CC did not affect yield when terminated about 1 week before planting corn [1].

\section{Summary and Conclusions}

This study comparing early- and late-terminated CC with different corn residue removal rates in rainfed and irrigated locations suggests that $\mathrm{CC}$ could increase levels of residue removal while preventing water erosion and potentially maintaining SOC. Early-terminated CC, due to low biomass yield, does not appear to allow increased levels of residue removal; however, late-terminated CC, with greater biomass production, could allow increased levels of removal. Late-terminated CC can offset residue removal-induced reductions in wet soil aggregate stability, leading to reductions in water erosion potential, regardless of irrigation regime. The increase in soil aggregation leads to fewer soil particles carried into surface waters by large rain events $[3,10,19]$. The reduction in water erosion could also mean reduced losses of nutrients and $C$, reducing risks of pollution to surface waters $[3,10,19]$. While there was no effect of residue removal on POM at the irrigated site, late-terminated CC increased POM, which suggests that CC could theoretically offset losses of labile fractions of soil organic matter from residue removal.

Late-terminated CC could offset the effects of residue removal on water erosion potential without reducing corn yields except in years when dry periods occur during early corn development. Early-terminated CC did not appear to offset any negative effects of residue removal on soil properties. From a cost-benefit analysis standpoint, early-terminated CC may not provide the economic benefits as discussed in a modeling study [27], but late-terminated CC could provide benefits to soil. Late-terminated CC did 
reduce corn yield in one of 3 years, suggesting that CC termination date may need to vary from year to year in order to balance levels of removal and yields. Under the conditions of this study, it appears that, in the short term (3 years), complete residue removal does not adversely affect soil properties when CC is added after removal and terminated late. Previous studies have suggested that only 30 or $50 \%$ of residue can be removed, but our results appear to suggest that higher rates of removal can be possible in some soils, depending on initial SOC concentration and use of CC to ameliorate the negative effects of removal. Further long-term ( $>3$ years) monitoring of residue removal and CC effects on soil properties is needed as changes may develop after three or more years of treatment imposition. Moreover, research on how CC seeding rate and termination date interactions influences $\mathrm{CC}$ effects on soil properties after residue removal is also needed. Overall, this 3-year study showed that late-terminated CC could offset residue removal-induced increases in water erosion potential and does not reduce corn yield in most years under the conditions of this study.
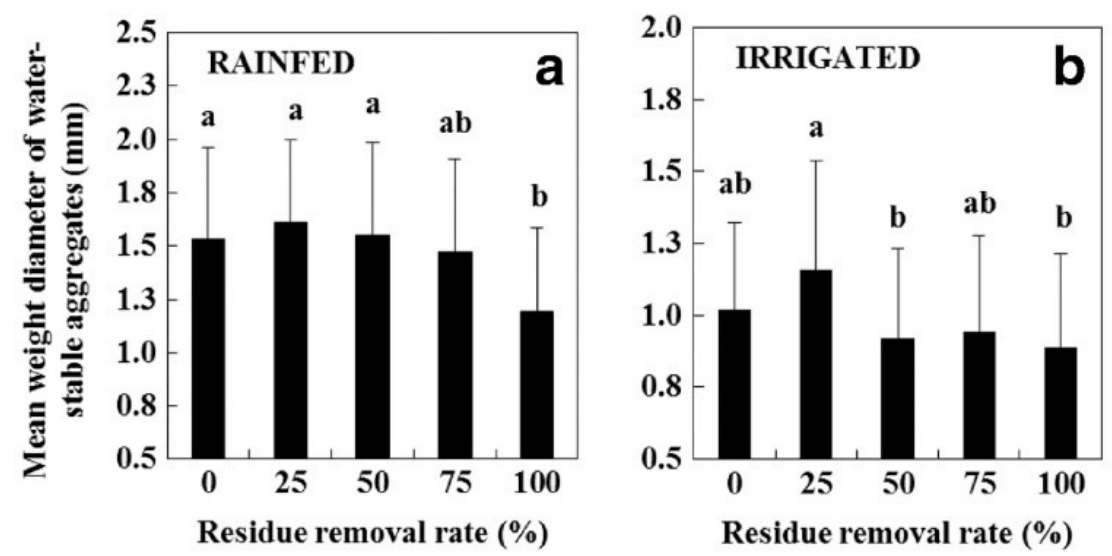

Fig. 1. Changes in mean weight diameter of water-stable aggregates under five corn residue removal rates at a rainfed site (a) and an irrigated site (b) in Nebraska. Data were collected in 2016. Differences for both sites were significant only at $p<$ 0.10. Different lowercase letters indicate significant differences among residue removal rates. Error bars are the standard deviation of the mean. 

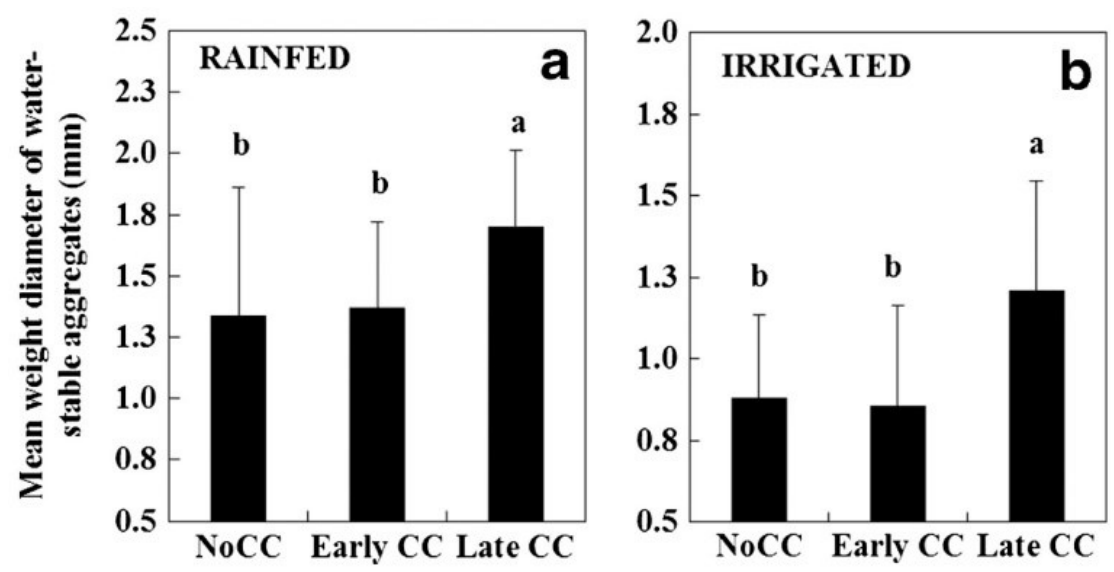

Fig. 2. Response of mean weight diameter of water-stable aggregates to three cover crop (CC) treatments [control (no CC), early-terminated CC (early CC), and late-terminated CC (late CC)] at a rainfed site (a) and an irrigated site (b) in Nebraska. Data were collected in 2016. Different lowercase letters denote statistical differences among CC treatments within a site. Error bars are the standard deviation of the mean.

Acknowledgments - This research work was funded by the Nebraska Environmental Trust through grant No. 16-189. The authors acknowledge the field assistance, maintenance, and coordination by Stuart Hoff at UNL's Roger's Memorial Farm and many student employees. Compliance with Ethical Standards

Conflict of interest - The authors declare that they have no conflict of interest.

\section{References}

1. Adler PR, Rau BM, Roth GW (2015) Sustainability of corn stover strategies in Pennsylvania. Bioenerg Res 8:1310-1320

2. Barthes B, Roose E (2002) Aggregate stability as an indicator of soil susceptibility to runoff and erosion; validation at several levels. Catena 47:425-437

3. Beniston JW, Shipitalo MJ, Lal R, Dayton EA, Hopkins DW, Jones F, Joynes A, Dungait JAJ (2015) Carbon and macronutrient losses during accelerated erosion under different tillage and residue management. Eur J Soil Sci 66:218225

4. Blake GR, Hartge KH (1986) Bulk density. Methods of soil analysis: part 1. SSSA Book Ser. 5. SSSA, Madison, WI, pp 363-375

5. Blanco-Canqui H, Lal R (2009) Corn stover removal for expanded uses reduces soil fertility and structural stability. Soil Sci Soc Am J 73:418-426

6. Blanco-Canqui H, Holman JD, Schlegel AJ, Tatarko J, Shaver TM (2013) Replacing fallow with cover crops in a semiarid soil: effects on soil properties. Soil Sci Soc Am J 77:1026-1034

7. Blanco-Canqui H, Ferguson RB, Jin VL, Schmer MR, Wienhold BJ, Tatarko J (2014) Can cover crop and manure maintain soil properties after stover removal from irrigated no-till corn? Soil Sci Soc Am J 78:1368-1377 
8. Blanco-Canqui H, Shaver TM, Lindquist JL, Shapiro CA, Elmore RW, Francis CA, Hergert GW (2015) Cover crops and ecosystem services: insights from studies in temperate soils. Agron J 107: 2449-2474

9. Blanco-Canqui H (2016) Growing dedicated energy crops on marginal lands and ecosystem services. Soil Sci Soc Am J 80:845-858

10. Blanco-Canqui H, Stalker AL, Rasby $R$, Shaver TM, Drewnoski ME, van Donk SJ, Kibet $L$ (2016a) Does cattle grazing and baling of corn residue increase water erosion? Soil Sci Soc Am J 80:168-177

11. Blanco-Canqui H, Tatarko J, Stalker AL, Shaver TM, van Donk SJ (2016b) Impacts of corn residue grazing and baling on wind erosion potential in a semiarid environment. Soil Sci Soc Am J 80:1027-1037

12. Cambardella CA, Gajda AM, Doran JW, Wienhold SBJ, Kettler TA (2001) Estimation of particulate and total organic matter by weight loss-on-ignition. In: Lal R (ed) Assessment methods for soil carbon. Lewis Publ, Boca Raton, FL, pp 349-359

13. Clark AJ, Decker AM, Meisinger JJ (1994) Seeding rate and kill date effects on hairy vetch-cereal rye cover crop mixtures for corn production. Agron J 86:1065-1070

14. Ferguson RB, Nienaber JA, Eigenberg RA, Woodbury BL (2005) Long-term effects of sustained beef feedlot manure application on soil nutrients, corn silage yield, and nutrient uptake. J Environ Qual 34:1672-1681

15. Feyereisen GW, Camargo GGT, Baxter RE, Baker JM, Richard TL (2013) Cellulosic biofuel potential of a winter rye double crop across the U.S. cornsoybean belt. Agron J 105:631-642

16. Graham RL, Nelson R, Sheehan J, Perlack RD, Wright LL (2007) Current and potential US corn stover supplies. Agron J 99:1-11

17. Halvorson AD, Stewart CE (2015) Stover removal affects no-till irrigated corn yields, soil carbon, and nitrogen. Agron J 107:1504-1512

18. Kemper WD, Rosenau RC (1986) Aggregate stability and size distribution. In: Methods of soil analysis. Part 1. Physical and mineralogical methods. (ed Klute A) p. 425-442. 2nd ed. SSSA Book Ser. 5. SSSA, Madison, WI

19. Kenney I, Blanco-Canqui H, Presley DR, Rice CW, Janssen K, Olson B (2015) Soil and crop response to stover removal from rainfed and irrigated corn. Glob Chang Biol Bioenergy 7:219-230

20. LeDuc SD, Zhang X, Clark CM, Izaurralde RC (2017) Cellulosic feedstock production on Conservation Reserve Program land: potential yields and environmental effects. Glob Chang Biol Bioenergy 9:460-468

21. Liska AJ, Yang H, Milner M, Goddard S, Blanco-Canqui H, Pelton MP, Fang XX, Zhu H, Suyker AE (2014) Biofuels from crop residue can reduce soil carbon and increase CO2 emissions. Nat Clim Chang 4:398-401

22. Moore KJ. Karlen DL, Lamkey KR (2014) Future prospects for corn as a biofuel crop. In: Compendium of bioenergy plants: corn (ed Goldman SL, Kole C) Pgs 331-352. CRC Press-Taylor and Francis Group, Boca Raton, FL 33487

23. Nelson DW, Sommers LE (1996) Total carbon, organic carbon, and organic matter: laboratory methods. In: Methods of soil analysis. Part 3. (ed Sparks DL) p. 961-1010. SSSA Book Ser. 5. SSSA, Madison, WI

24. Nielsen DC, Vigil MF (2005) Legume green fallow effect on soil water content at wheat planting and wheat yield. Agron J 97:684-689

25. Nielsen DC, Lyon DJ, Higgins RK, Hergert GW, Holman JD, Vigil MF (2016) Cover crop effect on subsequent wheat yield in the Central Great Plains. Agron J 108:243-256

26. Osborne SL, Johnson JMF, Jin VL, Hammerbeck AL, Varvel GE, Schumacher TE (2014) The impact of corn residue removal on soil aggregates and particulate organic matter. Bioenerg Res 7:559-567 
27. Pratt MR, Wallace ET, Muth DJ, Kladivko EJ (2014) Synergies between cover crops and corn stover removal. Agric Syst 130:67-76

28. Sainju UM, Singh BP (2001) Tillage, cover crop, and kill-planting date effects on corn yield and soil nitrogen. Agron J 93:878-886

29. SAS Institute. (2016) SAS Online Doc 9.1.3. SAS Inst., Cary, NC. http://support.sas.com/documentation/onlinedoc/stat/930/statug.pdf (accessed 5 Feb. 2017)

30. Schlegel AJ, Havlin JL (1997) Green fallow for the central Great Plains. Agron J 89:762-767

31. Schmer M, Jin VL, Wienhold BJ, Varvel GE, Follett RF (2014) Tillage and residue management effects on soil carbon and nitrogen under irrigated continuous corn. Soil Sci Soc Am J 78:1987-1996

32. Sesmero JP (2014) Corn residue supply in the irrigated Corn Belt. Bioenerg Res 7:728-743

33. Six J, Paustain K, Elliot ET, Combrink C (2000) Soil structure and organic matter I. Distribution of aggregate-size classes and aggregate associated carbon. Soil Sci Soc Amer J 64:681-689

34. Somerville C, Youngs H, Taylor C, Davis LSP (2010) Feedstocks for lignocellulosic biofuels. Science 329:790-792

35. Stetson SJ, Osborne SL, Schumacher TE, Eynard A, Chilom G, Rice J, Nichols KA, Pikul JL Jr (2012) Corn residue removal impact on topsoil organic carbon in a corn-soybean rotation. Soil Sci Soc Am J 76:1399-1406

36. Stewart CE, Follett RF, Pruessner EG, Varvel GE, Vogel KP, Mitchell RB (2015) Nitrogen and harvest effects on soil properties under rainfed switchgrass and no-till corn over 9 years: implications for soil quality. Glob Chang Biol Bioenergy 7:288-301

37. Tan ZX, Liu SG (2015) Corn Belt soil carbon and macronutrient budgets with projected sustainable stover harvest. Agric Ecosys Environ 212:119-126

38. Tilman D, Socolow R, Foley JA, Hill J, Larson E, Lynd L, Pacala S, Reilly J, Searchinger T, Somerville C, Williams R (2009) Beneficial biofuels-the food, energy, and environment trilemma. Sci 325:270-271

39. Unger PW, Vigil MF (1998) Cover crop effects on soil water relationships. J Soil Water Conserv 53:200-207

40. USDA-NASS (2015) United States Department of Agriculture, National Agricultural Statistics Service. https://www.nass.usda.gov/Statistics by Subject/?sector=CROPS (accessed 9 Sept. 2016)

41. Wegner BR, Kumar S, Osborne SL, Schumacher TE, Vahyala IE, Eynard A (2015) Soil response to corn residue removal and cover crops in eastern South Dakota. Soil Sci Soc Am J 79:1179-1187

42. Wilhelm WW, Johnson JMF, Hatfield JL, Voorhees WB, Linden DR (2004) Crop and soil productivity response to corn residue removal: a literature review. Agron J 96:1-17

43. Wilhelm WW, Johnson JMF, Karlen DL, Lightle DT (2007) Corn stover to sustain soil organic carbon further constrains biomass supply. Agron J 99:1665-1667

Tables follow .... 
Table 1. Mean temperature and precipitation during the 2013-2016 study years for UNL's Rogers Memorial Farm (eastern Nebraska, rainfed) and South Central Agricultural Lab (south central Nebraska, irrigated). Irrigation amount listed in parentheses for the irrigated site.

\begin{tabular}{|c|c|c|c|c|c|c|c|c|c|}
\hline $\begin{array}{l}\text { Mean } \\
{ }^{\circ} \mathrm{C}\end{array}$ & peratu & & & & $\begin{array}{l}\text { Precipitatio } \\
\mathrm{mm}\end{array}$ & & & & \\
\hline 2013 & 2014 & 2015 & 2016 & 30-year mean & 2013 & 2014 & 2015 & 2016 & 30 -year mean \\
\hline
\end{tabular}

\begin{tabular}{|c|c|c|c|c|c|c|c|c|c|c|}
\hline \multicolumn{11}{|c|}{ Rainfed site } \\
\hline January & -3 & -5 & -2 & -4 & -4 & 10 & 0 & 0 & 10 & 19 \\
\hline February & -2 & -5 & -6 & 2 & -2 & 0 & 0 & 0 & 10 & 35 \\
\hline March & 2 & 3 & 6 & 9 & 4 & 30 & 0 & 0 & 50 & 55 \\
\hline April & 8 & 10 & 12 & 13 & 11 & 110 & 80 & 60 & 120 & 72 \\
\hline May & 16 & 18 & 16 & 17 & 17 & 170 & 100 & 210 & 210 & 123 \\
\hline June & 22 & 22 & 22 & 25 & 22 & 50 & 160 & 120 & 90 & 113 \\
\hline July & 23 & 22 & 24 & 25 & 25 & 10 & 10 & 90 & 160 & 110 \\
\hline August & 23 & 24 & 22 & 23 & 23 & 40 & 120 & 120 & 160 & 94 \\
\hline September & 21 & 18 & 21 & 21 & 18 & 60 & 170 & 340 & 80 & 75 \\
\hline October & 11 & 12 & 14 & 14 & 11 & 110 & 60 & 10 & 40 & 55 \\
\hline November & 3 & 1 & 7 & 8 & -6 & 30 & 0 & 60 & 20 & 42 \\
\hline December & -6 & 0 & 1 & -3 & -3 & 0 & 30 & 130 & 0 & 25 \\
\hline Annual & 10 & 10 & 11 & 13 & 10 & 620 & 730 & 1140 & 950 & 818 \\
\hline \multicolumn{11}{|c|}{ Irrigated site } \\
\hline January & -4 & -3 & -1 & -3 & -3 & 10 & 10 & 20 & 10 & 10 \\
\hline February & -1 & -5 & -3 & 2 & -2 & 30 & 10 & 10 & 40 & 12 \\
\hline March & 3 & 3 & 7 & 8 & 4 & 60 & 0 & 10 & 10 & 45 \\
\hline April & 8 & 11 & 12 & 12 & 10 & 70 & 60 & 63 & 133 & 64 \\
\hline May & 16 & 17 & 15 & 16 & 22 & 140 & 76 & 151 & 173 & 114 \\
\hline June & 22 & 22 & 22 & 25 & 45 & 30 & 176 & 230 & 5 & 95 \\
\hline July & 24 & 23 & 24 & 25 & 25 & 40 & $43(30)$ & $56(70)$ & $64(90)$ & 94 \\
\hline August & 23 & 23 & 23 & 23 & 24 & 80 & $179(70)$ & 32 (110) & $60(90)$ & 93 \\
\hline September & 21 & 18 & 21 & 20 & 21 & 30 & 49 & 40 & 66 & 64 \\
\hline October & 11 & 13 & 14 & 14 & 11 & 120 & 30 & 37 & 6 & 50 \\
\hline November & 3 & 1 & 7 & 8 & 4 & 30 & 10 & 50 & 20 & 32 \\
\hline December & -4 & -1 & 1 & -3 & -2 & 0 & 10 & 50 & 40 & 15 \\
\hline Annual & 10 & 10 & 12 & 12 & 13 & 640 & 700 & 750 & 530 & 688 \\
\hline
\end{tabular}

Sources of data were NRCS Scan (https://www.wcc.nrcs.usda.gov/scan/) for the rainfed site and WeatherUnderground (https://www.wunderground.com/us/ne/harvard) for the irrigated site. 
Table 2. Management details of the two experimental sites including a rainfed site (UNL's Rogers Memorial Farm) and an irrigated site (South Central Agricultural Lab) in eastern and south central Nebraska, respectively.

\begin{tabular}{|c|c|c|}
\hline Year & Date & Field management operations \\
\hline \multicolumn{3}{|c|}{ Rainfed site } \\
\hline \multirow[t]{2}{*}{2013} & 25-29 October & Residue removal treatments applied \\
\hline & 1 November & Rye planted at $67.25 \mathrm{~kg} \mathrm{ha}^{-1}$ \\
\hline \multirow[t]{8}{*}{2014} & 26 March & Anhydrous ammonia applied at $182 \mathrm{~kg} \mathrm{ha}^{-1}$ \\
\hline & 22 April & Early termination sprayed with glyphosate at $1.6 \mathrm{~L} \mathrm{ha}^{-1}$ \\
\hline & 5 May & Corn planted at 80,000 plants ha ${ }^{-1}$ and $46.7 \mathrm{~L} \mathrm{ha}^{-1} 10-34-0$ starter applied \\
\hline & 15 May & Late termination sprayed with glyphosate at $2.04 \mathrm{~L} \mathrm{ha}^{-1}$ \\
\hline & 20 May & Residual herbicide applied $7.72 \mathrm{~L} \mathrm{ha}^{-1}$ Lumax; $_{0.58} \mathrm{~L} \mathrm{ha}^{-1} 2-4, \mathrm{D}$ \\
\hline & 19 June & Post-emerge herbicide applied $2.81 \mathrm{~L} \mathrm{ha}^{-1}$ atrazine \\
\hline & 30-31 October & Residue removal treatments applied \\
\hline & 31 October & Rye planted at $67.25 \mathrm{~kg} \mathrm{ha}^{-1}$ \\
\hline \multirow[t]{7}{*}{2015} & 17 March & Anhydrous ammonia applied at $182 \mathrm{~kg} \mathrm{ha}^{-1}$ \\
\hline & 11 April & Early termination sprayed with glyphosate at $2.05 \mathrm{~L} \mathrm{ha}^{-1}$ \\
\hline & 30 April & Corn planted at 80,000 plants ha- $\mathrm{ha}^{-1}$ and $46.7 \mathrm{~L} \mathrm{ha}^{-1} 10-34-0$ starter applied \\
\hline & 31 April & $\begin{array}{l}\text { Late termination sprayed with glyphosate at } 2.04 \mathrm{~L} \mathrm{ha}^{-1} \text { and residual herbicides } \\
7.72 \mathrm{~L} \mathrm{ha}^{-1} \mathrm{Lumax}^{0} 0.58 \mathrm{~L} \mathrm{ha} \mathrm{h}^{-1} 2-4, \mathrm{D}\end{array}$ \\
\hline & 18 June & Post emerge herbicide applied $2.81 \mathrm{~L} \mathrm{ha}^{-1}$ atrazine \\
\hline & 27-29 October & Residue removal treatments applied \\
\hline & 30 October & Rye planted at $67.25 \mathrm{~kg} \mathrm{ha}^{-1}$ \\
\hline \multirow[t]{7}{*}{2016} & $21 \mathrm{March}$ & Anhydrous ammonia applied at $205 \mathrm{~kg} \mathrm{ha}^{-1}$ \\
\hline & 4 April & Early termination sprayed with glyphosate at $2.05 \mathrm{~L} \mathrm{ha}^{-1}$ \\
\hline & 12 April & Residual herbicide applied Corvus at $0.41 \mathrm{~L} \mathrm{ha}^{-1}$ \\
\hline & 26 April & Corn planted at 80,000 plants ha-1 and $46.7 \mathrm{~L} \mathrm{ha}^{-1} 10-34-0$ starter applied \\
\hline & 9 May & Late termination sprayed with glyphosate at $2.04 \mathrm{~L} \mathrm{ha}^{-1}$ \\
\hline & 13 June & Post emerge herbicide applied $2.81 \mathrm{~L} \mathrm{ha}^{-1}$ atrazine and $0.58 \mathrm{~L} \mathrm{ha}^{-1} 2-4, \mathrm{D}$ \\
\hline & 24-27 October & Residue removal treatments applied \\
\hline \multicolumn{3}{|c|}{ Irrigated site } \\
\hline \multirow[t]{2}{*}{2013} & 21 October & Residue removal treatments applied \\
\hline & 24 October & Rye planted at $56 \mathrm{~kg} \mathrm{ha}^{-1}$ \\
\hline \multirow[t]{6}{*}{2014} & 17 April & Early termination sprayed with glyphosate at $2.33 \mathrm{~L} \mathrm{ha}^{-1}$ \\
\hline & Late April & Fertilizer applied-liquid UAN coulter-banded between old rows \\
\hline & 7 May & Corn planted at 79,074 plants ha ${ }^{-1}$ \\
\hline & 9 May & Late termination sprayed with $7.01 \mathrm{~L} \mathrm{ha}^{-1}$ Lexar and glyphosate at $2.33 \mathrm{~L} \mathrm{ha}^{-1}$ \\
\hline & $\begin{array}{r}21 \text { and } 28 \\
\text { October }\end{array}$ & Residue removal treatments applied \\
\hline & 30 October & Rye planted at $67.25 \mathrm{~kg} \mathrm{ha}^{-1}$ \\
\hline \multirow[t]{6}{*}{2015} & 13 April & Early termination sprayed glyphosate at $3.51 \mathrm{~L} \mathrm{ha}^{-1}$ \\
\hline & 30 April & Fertilization with $224 \mathrm{~kg} \mathrm{~N} \mathrm{ha}^{-1}$ liquid UAN coulter-banded \\
\hline & 1 May & Corn planted at 84,015 plants ha ${ }^{-1}$ \\
\hline & 5 May & Late termination sprayed with $7.01 \mathrm{~L} \mathrm{ha}^{-1}$ Lexar and $4.68 \mathrm{~L} \mathrm{ha}^{-1}$ glyphosate \\
\hline & $\begin{array}{l}2 \text { and } 3 \\
\quad \text { November }\end{array}$ & Residue removal treatments applied \\
\hline & 3 November & Rye planted at $112 \mathrm{~kg} \mathrm{ha}^{-1}$ \\
\hline \multirow[t]{7}{*}{2016} & 8 April & Early termination sprayed with glyphosate at $3.5 \mathrm{~L} \mathrm{ha}^{-1}$ \\
\hline & 24 April & Fertilized with $247 \mathrm{~kg} \mathrm{~N}$ ha $^{-1}$ liquid UAN coulter-banded \\
\hline & 5 May & Late termination sprayed with $2.92 \mathrm{~L} \mathrm{ha}^{-1}$ glyphosate \\
\hline & 13 May & Corn planted at 84,015 plants ha ${ }^{-1}$ \\
\hline & 14 May & Late termination sprayed with $5.85 \mathrm{~L}$ Acuron $\mathrm{ha}^{-1}$ and $1.17 \mathrm{~L} \mathrm{ha}^{-1}$ glyphosate \\
\hline & $\begin{array}{l}13,16,17 \\
\text { October }\end{array}$ & Residue removal treatments applied \\
\hline & 31 October & Rye planted at $112 \mathrm{~kg} \mathrm{ha}^{-1}$ \\
\hline
\end{tabular}


Table 3. Impact of five corn residue removal rates and rye cover crop termination dates on soil organic $\mathrm{C}$, total soil $\mathrm{N}$, and total particulate organic matter (POM) for the 0 - to $5-\mathrm{cm}$ depth at two sites in Nebraska.

\begin{tabular}{|c|c|}
\hline $\begin{array}{l}\text { Treatments } \\
\qquad\left(\mathrm{g} \mathrm{kg} \mathrm{soil}^{-1}\right)\end{array}$ & $\begin{array}{r}\text { Soil organic C } \\
\left(\mathrm{g} \mathrm{kg} \mathrm{soil}^{-1}\right)\end{array}$ \\
\hline
\end{tabular}

\section{Rainfed site}

Residue removal rate

\begin{tabular}{|c|c|c|c|}
\hline 0 & 27.1 & 2.6 & 13.2 \\
\hline 25 & 29.2 & 2.8 & 14.4 \\
\hline 50 & 28.6 & 2.8 & 13.8 \\
\hline 75 & 26.5 & 2.6 & 12.4 \\
\hline 100 & 26.6 & 2.5 & 16.8 \\
\hline \multicolumn{4}{|l|}{ ver crop treatment } \\
\hline No cover crop & 26.9 & 2.6 & 13.1 \\
\hline Early termination & 27.3 & 2.6 & 15.4 \\
\hline Late termination & 28.7 & 2.8 & 13.8 \\
\hline rameter & $p$ value & & \\
\hline Residue removal & 0.53 & 0.46 & 0.61 \\
\hline Cover crop & 0.46 & 0.14 & 0.57 \\
\hline Cover crop $\times$ residue removal & 0.17 & 0.28 & 0.60 \\
\hline \multicolumn{4}{|l|}{$\begin{array}{l}\text { igated site } \\
\text { sidue removal rate }\end{array}$} \\
\hline 0 & 25.5 & 2.6 & 15.7 \\
\hline 25 & 25.1 & 2.5 & 15.3 \\
\hline 50 & 25.2 & 2.8 & 14.2 \\
\hline 75 & 24.5 & 2.8 & 16.1 \\
\hline 100 & 25.2 & 2.5 & 13.9 \\
\hline \multicolumn{4}{|l|}{ ver crop treatment } \\
\hline No cover crop & 23.9 & 2.5 & $14.3 b$ \\
\hline Early termination & 26.0 & 2.7 & $14.5 b$ \\
\hline Late termination & 25.4 & 2.7 & $16.4 a$ \\
\hline rameter & $p$ value & & \\
\hline Residue removal & 0.97 & 0.48 & 0.20 \\
\hline Cover crop & 0.26 & 0.59 & 0.027 \\
\hline Cover crop $\times$ residue removal & 0.26 & 0.08 & 0.36 \\
\hline
\end{tabular}

Data were collected in 2016. Different lowercase letters denote differences among cover crop treatments. No letter denotes no statistical differences. 
Table 4. Impact of cover crop termination date and five corn residue removal rates on rye cover crop biomass yield at two sites in Nebraska.

Cover crop treatments

Residue removal rate (\%)

Cover crop biomass yield $\left(\mathrm{Mg} \mathrm{ha}^{-1}\right)$
2014

2016

Rainfed site

Early termination

$0.023 B$

$0.029 \mathrm{~B}$

$0.030 \mathrm{~B}$

$0.048 \mathrm{~B} \quad 1.03 \mathrm{~B}$

50

75

$\begin{array}{lc} & 100 \\ \text { Late termination } & 0\end{array}$

$0.042 B$

$0.033 \mathrm{~B}$

$0.20 \mathrm{~A}$

$0.43 \mathrm{~A}$

$0.35 \mathrm{~A}$

$0.25 \mathrm{~A}$

$0.39 \mathrm{~A}$

$0.088 \mathrm{~B}$

$1.93 \mathrm{~B}$

$1.28 \mathrm{~B}$

$0.10 \mathrm{~B} \quad 1.30 \mathrm{~B}$

$0.11 \mathrm{~B} \quad 1.50 \mathrm{~B}$

$1.24 \mathrm{bA} \quad 2.05 \mathrm{bA}$

25

3.50aA

$1.28 \mathrm{bA}$

2.63abA

75

Parameter

Residue removal

Cover crop

Cover crop $\times$ residue removal

0.17

$1.51 \mathrm{bA}$

$3.48 \mathrm{aA}$

100

2.34aA

$3.35 \mathrm{aA}$

\section{Irrigated site}

Early termination

$<0.001$

0.15

0.007

$<0.001$

0.03

0.002

$<0.001$

0.31

$\begin{array}{lcc}0.12 \mathrm{bB} & 0.12 \mathrm{~B} & 0.37 \mathrm{~B} \\ 0.12 \mathrm{abB} & 0.12 \mathrm{~B} & 0.46 \mathrm{~B} \\ 0.14 \mathrm{abB} & 0.22 \mathrm{~B} & 0.32 \mathrm{~B} \\ 0.16 \mathrm{abB} & 0.24 \mathrm{~B} & 0.50 \mathrm{~B} \\ 0.19 \mathrm{aB} & 0.27 \mathrm{~B} & 0.58 \mathrm{~B} \\ 2.68 \mathrm{aA} & 1.50 \mathrm{~A} & 3.70 \mathrm{~A} \\ 1.94 \mathrm{bA} & 2.00 \mathrm{~A} & 4.29 \mathrm{~A} \\ 2.61 \mathrm{aA} & 2.32 \mathrm{~A} & 4.54 \mathrm{~A} \\ 2.03 \mathrm{abA} & 2.32 \mathrm{~A} & 4.07 \mathrm{~A} \\ 2.92 \mathrm{aA} & 1.99 \mathrm{~A} & 3.98 \mathrm{~A} \\ p \text { value } & & \\ 0.005 & 0.15 & 0.83 \\ <0.001 & <0.001 & <0.001 \\ <0.001 & 0.30 & 0.86\end{array}$

Parameter

Residue removal

0

25

50

75

Late termination

100

0

25

50

75

100

$<0.00$

0.86

Cover crop $\times$ residue removal

Means with different lowercase letters indicate significant differences among residue removal treatments within a cover crop treatment and year. Means with different uppercase letters indicate significant differences between early and late-terminated cover crop treatments within a year. 
Table 5. Mean corn grain yield under five corn residue removal rates and two rye cover crop termination dates at two sites in Nebraska.

\begin{tabular}{|c|c|c|c|c|}
\hline \multirow[t]{2}{*}{ Treatment } & \multicolumn{3}{|c|}{ Grain yield $\left(\mathrm{Mg} \mathrm{ha}^{-1}\right)$} & \multirow{2}{*}{$\begin{array}{l}\text { Across } \\
\text { years }\end{array}$} \\
\hline & 2014 & $015 \quad 20$ & & \\
\hline \multicolumn{5}{|l|}{ Rainfed site } \\
\hline \multicolumn{5}{|l|}{ Residue removal rate } \\
\hline 0 & 10.6 & 15.5 & 10.2 & 12.1 \\
\hline 25 & 9.7 & 15.9 & 10.1 & 11.9 \\
\hline 50 & 10.9 & 16.9 & 11.8 & 13.2 \\
\hline 75 & 10.1 & 15.9 & 12.1 & 12.7 \\
\hline 100 & 9.6 & 16.4 & 11.4 & 12.5 \\
\hline \multicolumn{5}{|l|}{ Cover crop treatment } \\
\hline No cover crop & 10.4 & $16.8 a$ & 11.0 & 12.7 \\
\hline Early termination & 10.3 & $16.8 a$ & 10.5 & 12.3 \\
\hline Late termination & 9.8 & $15.4 b$ & 11.8 & 12.3 \\
\hline Parameter & $p$ value & & & \\
\hline Residue removal & 0.28 & 0.30 & 0.37 & 0.53 \\
\hline Cover crop & 0.56 & 0.05 & 0.26 & 0.75 \\
\hline Cover crop $\times$ residue removal & 0.14 & 0.90 & 0.62 & 0.92 \\
\hline \multicolumn{5}{|l|}{ Irrigated site } \\
\hline \multicolumn{5}{|l|}{ Residue removal rate } \\
\hline 0 & 16.4 & $14.8 b$ & 17.2 & 16.1 \\
\hline 25 & 17.5 & $16.4 a$ & 16.8 & 16.9 \\
\hline 50 & 16.7 & $15.7 a b$ & 15.9 & 16.1 \\
\hline 75 & 17.3 & $16.9 a$ & 17.2 & 17.2 \\
\hline 100 & 16.8 & $16.2 a$ & 17.0 & 16.7 \\
\hline \multicolumn{5}{|l|}{ Cover crop treatment } \\
\hline No cover crop & 17.2 & $16.5 a$ & 16.9 & 16.9 \\
\hline Early termination & 17.1 & $16.1 \mathrm{a}$ & 16.8 & 16.7 \\
\hline Late termination & 16.6 & $15.4 \mathrm{~b}$ & 16.8 & 16.3 \\
\hline Parameter & $p$ value & & & \\
\hline Residue removal & 0.37 & 0.0014 & 0.98 & 0.11 \\
\hline Cover crop & 0.38 & 0.021 & 0.82 & 0.26 \\
\hline Cover crop $\times$ residue removal & 0.78 & 0.59 & 0.76 & 0.98 \\
\hline
\end{tabular}

Different lowercase letters indicate significant differences among treatments within the same study factor and year. No letter denotes no statistical differences. 